\title{
"Diagnosis of competencies in the meetings industry in Poland, Hungary and Ireland in post-COVID-19 period"
}

\begin{tabular}{|c|c|}
\hline AUTHORS & $\begin{array}{l}\text { Bartłomiej Walas (i) } \\
\text { R } \\
\text { Marek Nocoń (D) } \\
\text { Sandor Nemethy (D) } \\
\text { František Petrovič (D) } \\
\text { Anna Oleksa-Kaźmierczak (D) }\end{array}$ \\
\hline ARTICLE INFO & $\begin{array}{l}\text { Bartłomiej Walas, Marek Nocoń, Sandor Nemethy, František Petrovič and Anna } \\
\text { Oleksa-Kaźmierczak (2021). Diagnosis of competencies in the meetings industry } \\
\text { in Poland, Hungary and Ireland in post-COVID-19 period. Problems and } \\
\text { Perspectives in Management, 19(4),198-212. doi:10.21511/ppm.19(4).2021.17 }\end{array}$ \\
\hline DOI & http://dx.doi.org/10.21511/ppm.19(4).2021.17 \\
\hline RELEASED ON & Monday, 08 November 2021 \\
\hline RECEIVED ON & Thursday, 23 September 2021 \\
\hline ACCEPTED ON & Friday, 29 October 2021 \\
\hline LICENSE & $\begin{array}{l}(c) \text { EY } \\
\text { This work is licensed under a Creative Commons Attribution } 4.0 \text { International } \\
\text { License }\end{array}$ \\
\hline JOURNAL & "Problems and Perspectives in Management" \\
\hline ISSN PRINT & $1727-7051$ \\
\hline ISSN ONLINE & $1810-5467$ \\
\hline PUBLISHER & LLC "Consulting Publishing Company "Business Perspectives" \\
\hline FOUNDER & LLC "Consulting Publishing Company "Business Perspectives" \\
\hline
\end{tabular}

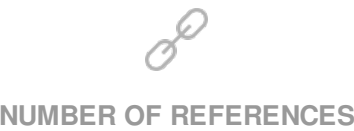

45
NUMBER OF FIGURES

4
NUMBER OF TABLES

9

(C) The author(s) 2021. This publication is an open access article. 


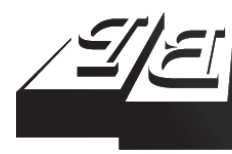

\section{BUSINESS PERSPECTIVES}

LLC "CPC "Business Perspectives" Hryhorii Skovoroda lane, 10, Sumy, 40022, Ukraine www.businessperspectives.org
Received on: $23^{\text {rd }}$ of September, 2021 Accepted on: $29^{\text {th }}$ of October, 2021 Published on: $8^{\text {th }}$ of November, 2021

๑) Bartłomiej Walas, Marek Nocoń, Sandor Nemethy, František Petrovič, Anna Oleksa-Kaźmierczak, 2021

Bartłomiej Walas, Ph.D., Professor, Dean of Faculty of Tourism and Leisure, the University College of Tourism and Ecology, Poland.

Marek Nocoń, Ph.D., Professor, Dean of Faculty of Social Sciences, the University College of Tourism and Ecology, Poland.

Sandor Nemethy, Ph.D., Professor, Faculty of Tourism and Leisure, the University College of Tourism and Ecology, Poland.

František Petrovič, Ph.D., Professor Faculty of Tourism and Leisure, the University College of Tourism and Ecology, Poland.

Anna Oleksa-Kaźmierczak, M.Sc., Assistant, Faculty of Computer Sciences, the University College of Tourism and Ecology, Poland. (Corresponding author)
Bartłomiej Walas (Poland), Marek Nocoń (Poland), Sandor Nemethy (Poland), František Petrovič (Poland), Anna Oleksa-Kaźmierczak (Poland)

\section{DIAGNOSIS OF COMPETENCIES IN THE MEETINGS INDUSTRY IN POLAND, HUNGARY AND IRELAND IN POST-COVID-19 PERIOD}

\begin{abstract}
The freezing of economies due to the COVID-19 pandemic caused damage not only on the sales side but also on the labor market due to the outflow of staff from companies specializing in the organization of meetings. The return of the meetings industry sector to the development path will involve skillful change management, including in the area of competencies and skills. To inventory and assess the competencies of employees in the meetings industry, this study was carried out among specialized enterprises in the meetings industry in Poland, Hungary, and Ireland, on samples of two research groups, i.e. the Director General (CEO) and operational employees based on questionnaires and individual in-depth interviews (IDI). The obtained results allowed to establish the hierarchy of self-assessment of own managerial competencies, assessment of the competencies of the CEO by the employees, areas of increasing team competencies, and areas of staff development in the sector shortly, contributing to the recovery from the pandemic crisis.

Raising the competencies and qualifications of employees is perceived as one of the most powerful tools for overcoming the pandemic crisis, obtaining $68 \%$ positive in dications among CEOs in Poland, 77\% indications in Hungary, and $84 \%$ in Ireland. In all analyzed countries, the meetings industry is indicated as a strategic product of the tourist market. Among the planned long-term actions aimed at overcoming the pandemic crisis, increasing employee competencies is perceived as an opportunity for the companies operating the meetings industry sector ( $90 \%$ in Poland, and $80 \%$ in Hungary and Ireland).
\end{abstract}

Keywords

meeting industry, tourism, management, competencies, qualifications, skills, MICE, COVID-19

\section{JEL Classification J89, Z32, M12}

\section{INTRODUCTION}

The term "meeting industry" replaced the previously used (but still functioning) terms of "business tourism" and "MICE sector" (an acronym derived from $\mathrm{M}$ - Meetings, I - Incentives, C - Congresses or Conferences, and E - Exhibitions or Events). The World Tourism Organization (UNWTO) uses the term "meetings industry" to denote organization, promotion, sales, and service delivery for the association, government and corporate meetings, incentive travel, seminars, conventions and conferences, business events, technical visits, exhibitions, and fairs (Celuch, 2014; Swarbrooke \& Horne, 2001). The cities are building their economic and tourism potential by relying on the meetings industry (Zmyślony \& Piechota, 2014). The number of international conferences is a significant measure of economic competitiveness used to build recognized world rankings of cities e.g., Global City Index, Global City Competitiveness Index, and Cities of Opportunity. Hence, for many cities, the meetings industry becomes the industry 
of economic development, emphasized in strategic documents (Walas, 2021), and the managing the meetings industry has an organizational structure, often of a public-private nature, commonly called the Convention Bureau. In the group of meeting industry actors, the following are most often mentioned: Professional Congress/Conferences Organizer - PCO, Incentive Travel Organizers, Destination Management Companies - DCM, Convention Bureau - CB, and Events Agency (Borodako et al., 2015). It is the representatives of these institutions (excluding $\mathrm{CB}$ ) that are included in this study. As indicated by Marez (2020), the United Nations World Tourism Organization confirms that identifying and deepening the competencies of qualifications may turn out to be the way of rebuilding the sector.

\section{LITERATURE REVIEW}

The literature review was made in order to show the importance of the meetings industry for the economy and the role of employees' competencies within effective management. The denominator of the analysis is the probable post-pandemic market situation. Until the outbreak of the COVID-19 pandemic, the MICE sector, nowadays known as the meetings industry, was a thriving and rapidly growing industry, and its role in the economy was constantly growing (Statista Research Department, 2021). Globally, the MICE industry is dominated by the meetings segment (mainly face-to-face). In Europe, $18 \%$ of trips were business-related, while the remaining MICE segments collectively only get $6 \%$ share (of which $48 \%$ conference tourism, $42 \%$ - exhibitions, $10 \%$ - incentive trips). The largest market share is held by Germany, France, and Switzerland, which account for around one-third of European business tourism. The multi-year trend, measured before the pandemic, was extremely favorable (Allied Market Research, 2019). In regional terms, the position of Europe as a region for the reception of events also indicated its growing importance. The 2019 statistics of the International Congress and Convention Association ICCA recorded 13,254 rotating association meetings, which was the highest recorded annual number with an increase of 317 meetings compared to the previous year (ICCA, 2020).

The COVID-19 pandemic has radically changed the market situation. Strategic Alliance of the National Convention Bureaux of Europe has published the results of a study on the impact of the coronavirus on the European meetings industry. The analysis aims to create a constructive description of the process of recovering the meetings and conferences sector from the crisis and to develop the possible scenarios reflecting the scope of the impact of the current situation (Polish Tourism Organization, 2020). According to the basic model, participation in both national and international events will continue to be influenced by some negative sentiment, reducing the number of participants by $25 \%$ in 2021 and $5 \%$ in 2022, before finally recovering in 2023. The pessimistic scenario considers alternative forecasts assuming a decline in the number of conference tourism participants between $36 \%$ and $77 \%$ in 2020 , followed by a sharp or more prolonged recovery, respectively. Government restrictions on the size of meetings are also expected in 2021, as well as a stronger impact of negative moods among potential participants (resulting from their concerns) and a full improvement in 2024 at the earliest. Analysis of the impact of the pandemic on the MICE sector has been described in many countries, such as the United Arab Emirates (Aburumman, 2020).

One of the areas of reconstruction of this market segment is not only the demand for events but also the improvement of competencies. Various studies to date show that skills rated most important are personal skills, then social skills, with knowledge skills rated as least important (Burzyński, 2018; Pilcher et al., 2017; Bevins et al., 2020; Kupczyk \& Stor, 2018; Hong, 2009; CTHRC, 2011; Shum et al., 2018).

Focusing on the quality of services, improving the skills of MICE specialists, and deepening the professional knowledge of specialists based on current trends will contribute to strengthening the professional industry, especially in the post-pandemic period. The skills of the MICE sector employees are especially important in the development of their careers (Górniak et al., 2015).

The greatest challenge is the competency gap, which may systematically increase, considering 
the growing demand for qualified employees. The competency gap has been defined as a shortage of skills or qualifications compared to those desired for a given job position or as maladjustment of the competency potential to the requirements necessary to achieve the set goals. Staff problems, according to employers and experts in the broadly understood tourism sector, are currently the most bothering issue of the domestic and European labor market (Argyle, 2002). It is worth noting, however, that the problem is the quality of competencies from mid-2021; there is also a noticeable shortage of staff, due to the departure of employees to other sectors. The analysis of studies and reports on the situation in the labor market clearly indicates that economic development and investment growth largely depend on the possibility of acquiring qualified employees (Winterton et al., 2006; Trinder, 2008; Nagarjuna, 2016).

Employee's professional competencies are perceived through the prism of knowledge, skills, and social competencies (Cedefop, 2020), including descriptors constituting the reference framework for learning outcomes, resulting from the recommendations of the European Qualifications Framework (EQF) and through this EQF to the levels of qualifications in individual EU countries (Helgoy \& Homme, 2015; Next Tourism Generation Alliance, 2020). Globalization and rapidly changing skill requirements, like those triggered and accelerated by the COVID-19 pandemic, and the trends which can be observed in the gig economy, change competency needs (EC, 2008).

Qualifications Framework and the Integrated Qualifications System (Colardyn \& Bjornavold, 2014) are based on three categories:

- knowledge - a set of descriptions of objects and facts, principles, theories, and practices, assimilated in the learning process, relating to the field of learning or professional activity;

- $\quad$ skills - the ability acquired in the learning process to perform tasks and solve problems relevant to the field of learning or professional activity;

- social competencies (abilities) - the ability to shape one's development as well as autono- mous and responsible participation in professional and social life, considering the ethical context of one's conduct.

The solutions that the Integrated Qualification System is introducing are a response to the changes in the labor market and economy. The experience of many European countries shows that the introduction of a system based on the qualifications framework will result in the growing number of people interested in formal recognition of their competencies and raising their qualifications which will not only affect people's professional situation but also their sense of security in the labor market (Smółka, 2008).

Regardless of the differences in the understanding of social competencies, they are recognized as properties that determine the effectiveness of the functioning of an individual and a team (Wybrańczyk, 2021; Whiddett \& Hollyforde, 2003). Modern efficient management aims to create a competitive advantage through the speed of reaction to new opportunities and problems, the flexibility of both labor resources and organizational structure, and then the integration of all resources. Competencies are also defined as the scope of knowledge, skills, and responsibilities, as well as powers of attorney and powers granted on the basis of qualifications to act and decide and make judgments (Phelan et al., 2009). The issue of the competencies has now become the subject of discussions among entrepreneurs in the sector, looking for both conditions for reconstruction and competitiveness, which are expressed, among others, by the Kaohsiung Protocol - Strategic Recovery Framework for the Global Events Industry (ICCA, 2020) and the Cracow Network Protocol (Błaszczyk et al., 2021). The need for competence development of MICE employees, and thus the reconstruction of the industry, will also affect the functioning of the entire tourist market. The ICCA Kaohsiung protocol is a strategic framework to revitalize the conduct of global meetings and events, as the COVID-19 pandemic is becoming a catalyst accelerating the transformation of this sector (Wang et al., 2010). Many of the macro and micro trends listed in the protocol relate directly to the competency level. In addition, the Cracow Network Protocol is an extremely interesting initiative, indicating, inter alia, the 
need to develop competencies. The document was created by representatives of the Cracow MICE industry as an introduction to a joint operating strategy and was published in March 2021.

\section{METHODOLOGY AND HYPOTHESIS}

Based on the described phenomena and the pandemic situation, the purpose of this study is shaped, namely the diagnosis of competencies of employees in the meetings industry sector. The assessment covered the competencies and needs in two groups of respondents in three countries, namely Poland, Hungary, and Ireland conducted in early 2021 with two groups of respondents. The first group was CEOs, and the second group was the operating staff of companies in this sector. The hypothesis posed is that the level of competencies in sector's enterprises is assessed as high and their improvement mainly concerns soft skills and is an opportunity for development and recovery from the crisis caused by the COVID-19 pandemic. Among planned long-term actions to recover from the pandemic crisis raising the competencies of employees is perceived as an opportunity for the company (90\% in Poland, and $80 \%$ in Hungary and Ireland). The scope of the study included:

- social competencies to check the competency gap;

- $\quad$ aggregate employee competencies;

- self-assessment of own managerial competencies of the CEO;

- assessment of the CEO's competencies by employees;

- the level of personality traits of the company's team;

- areas of improving the team's competencies; and

- areas of personnel development in the near future.

The meetings industry is a complex and fragmented market that connects the interests of many stakeholders. Among them, there are five categories of public and private institutions that play an important role in the preparation or organization of events. This group includes the most frequent- ly mentioned Professional Congress Organizer (PCO), incentive travel organizers, Destination Management Companies (DMC), organizers of fairs-exhibitions, and Convention Bureau (CB). Moreover, it was the representatives of four categories of enterprises (excluding CB) that constituted the group of respondents. Hotel facilities and venues were excluded too from the research sample because they were considered event locations.

The empirical analysis was based on the questionnaires of two surveys conducted using the CAWI technique from among companies representing the above four groups of institutions. The selection of respondents for the sample was based on a database of enterprises recommended by Convention Bureaux.

In each country (Poland, Ireland, and Hungary), in line with the concept, 30 surveys with employers/managers (CEO), a minimum of 20 with employees, and 15 in-depth individual interviews (IDI) with some of the CEOs were conducted. When assessing the representativeness of the sample size, it should be considered that, for example, in Poland, the number of officially recommended (certified) PCOs is limited and amounts to only 19 companies. It is similar in other countries. Hence, the selection is representative and illustrated in Tables 1-3.

Table 1. Structure of the research sample

Source: Own study.

\begin{tabular}{l|c:c:c}
\hline Position in company & Poland & Hungary & Ireland \\
\hline \multicolumn{4}{c}{ Number of respondents } \\
\hline CEO & 31 & 30 & 30 \\
Employees & 23 & 27 & 24 \\
\hline Total & 54 & 57 & 54 \\
\hline \multicolumn{4}{c|}{ Number of IDI } \\
\hline CEO & 17 & 15 & 15 \\
\hline
\end{tabular}

Table 2. Type of business activity - CEO

\begin{tabular}{l|c|c|c} 
& \multicolumn{3}{c}{ Source: Own study. } \\
\hline $\begin{array}{c}\text { Type of business } \\
\text { activity }\end{array}$ & Poland & Hungary & Ireland \\
\hline DMC-PCO & 14 & 10 & 14 \\
\hline $\begin{array}{l}\text { Organizer of incentive trips } \\
\text { Event agency }\end{array}$ & 7 & 6 & 5 \\
\hline $\begin{array}{l}\text { Organizer of fairs and } \\
\text { exhibitions }\end{array}$ & 2 & 8 & 7 \\
\hline Total & 31 & 7 & 4 \\
\hline
\end{tabular}


Table 3. Type of business activity- employees

Source: Own study.

\begin{tabular}{l|c:c:c}
\hline \multicolumn{1}{c}{ Type of business activity } & Poland & Hungary & Ireland \\
\hline $\mathrm{DMC}-\mathrm{PCO}$ & 10 & 5 & 8 \\
\hdashline Organizer of incentive trips & 3 & 7 & 5 \\
\hdashline Event agency & 7 & 5 & 6 \\
Organizer of fairs and exhibitions & 3 & 10 & 5 \\
Total & 23 & 27 & 24 \\
\hline
\end{tabular}

The structure of the questions was mainly based on the Likert scale and the results were divided into two groups: competencies in the opinion of managers (CEO) and competencies of the CEOs in the opinion of employees. Interviews with CEOs allowed for the identification most pressing problems of the sector requiring solutions in terms of competencies.

\section{RESULTS}

\subsection{Competencies in the opinion of managers (CEO)}

Managers faced a self-assessment of their managerial competencies (Figure 1), assessed on a scale from 1 (lowest competencies) to 5 (highest competencies). At the highest level (5 points), the least numerous groups assessed their competencies related to delegating tasks (11\%) and stress resistance $(12 \%)$. In contrast, the highest indicators (5 and 4 points) were assigned to leadership (20\%), organization (36\%), strategic thinking (32\%), and project management (29\%).
The social competencies of the team (Table 4) of the surveyed company, assessed on a scale from 5 (the highest competencies) to 1 (the lowest competencies). Nearly half of the respondents indicated ethics in contacts with clients (41\%) and every third (34\%) ethics at work. On the other hand, the lowest (1-2 points) level of competencies was indicated regarding international experience $(21 \%)$ and between $11 \%$ and $13 \%$ of responses concerned raising qualifications, work in information noise, emotional bond with the company, written communication, cross-linking skills, building local partnerships or willingness to learn.

Table 4. Social competencies of the enterprise team

Source: Own study.

\begin{tabular}{|c|c|c|c|c|c|}
\hline Competency & 5 & 4 & 3 & 2 & 1 \\
\hline $\begin{array}{l}\text { Building relationships with } \\
\text { customers }\end{array}$ & $22 \%$ & $49 \%$ & $26 \%$ & $3 \%$ & $0 \%$ \\
\hline Ethics at work & $34 \%$ & $37 \%$ & $26 \%$ & $3 \%$ & $0 \%$ \\
\hline $\begin{array}{l}\text { Ethics in dealing with } \\
\text { clients }\end{array}$ & $41 \%$ & $39 \%$ & $15 \%$ & $4 \%$ & $0 \%$ \\
\hline $\begin{array}{l}\text { Interpersonal } \\
\text { communication }\end{array}$ & $18 \%$ & $43 \%$ & $35 \%$ & $3 \%$ & $0 \%$ \\
\hline Availability & $23 \%$ & $46 \%$ & $27 \%$ & $4 \%$ & $0 \%$ \\
\hline $\begin{array}{l}\text { Coping with conflict } \\
\text { situations }\end{array}$ & $15 \%$ & $42 \%$ & $39 \%$ & $3 \%$ & $0 \%$ \\
\hline $\begin{array}{l}\text { Solving problems and } \\
\text { conflicts }\end{array}$ & $14 \%$ & $48 \%$ & $33 \%$ & $5 \%$ & $0 \%$ \\
\hline Proper self-presentation & $16 \%$ & $48 \%$ & $30 \%$ & $5 \%$ & $0 \%$ \\
\hline $\begin{array}{l}\text { Motivating oneself and } \\
\text { others }\end{array}$ & $23 \%$ & $33 \%$ & $36 \%$ & $9 \%$ & $0 \%$ \\
\hline
\end{tabular}

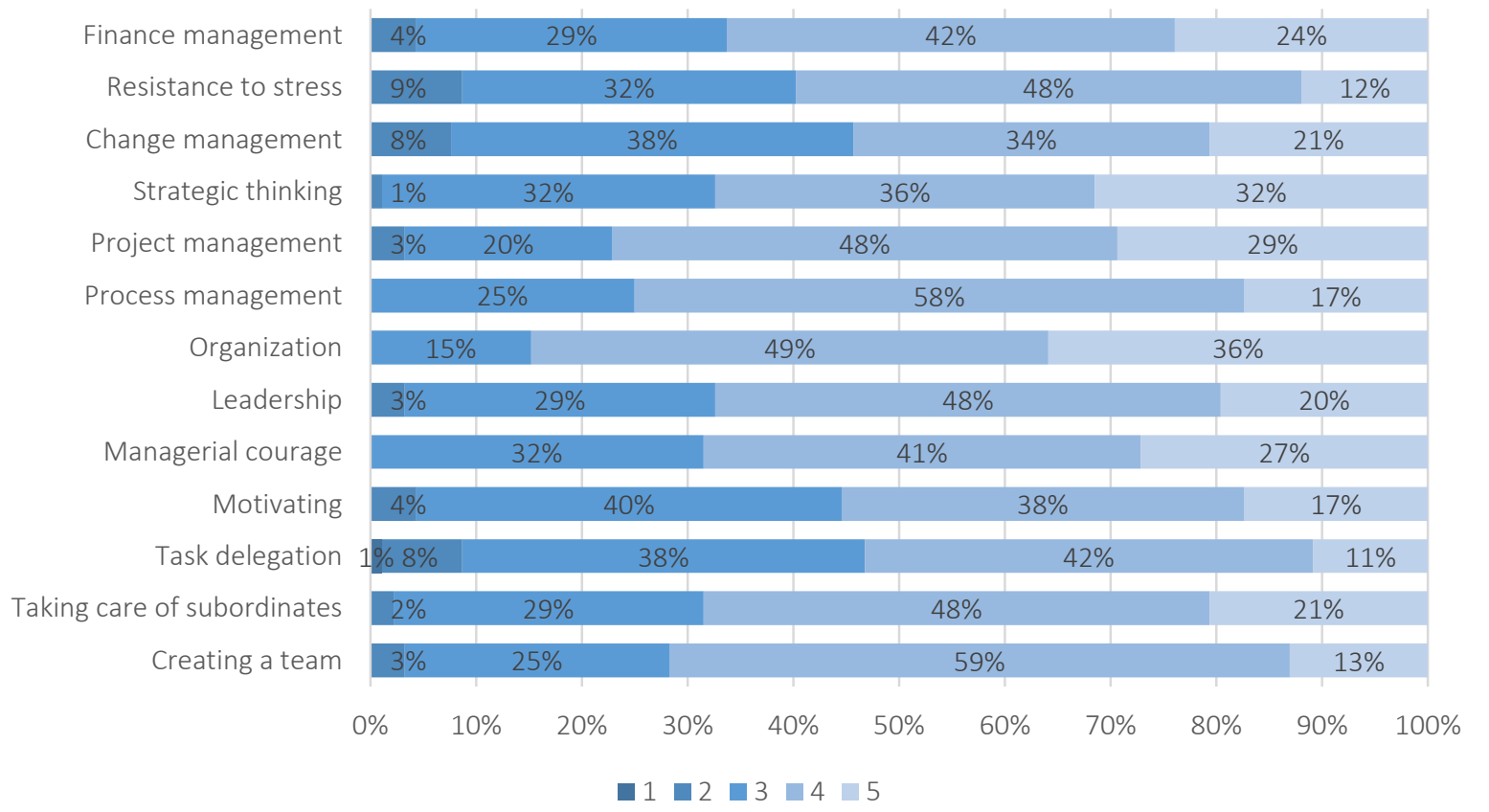

Figure 1. Managerial competencies of the CEO 
Table 4 (cont.). Social competencies of the enterprise team

\begin{tabular}{|c|c|c|c|c|c|}
\hline Competency & 5 & 4 & 3 & 2 & 1 \\
\hline $\begin{array}{l}\text { Emotional bond with the } \\
\text { company }\end{array}$ & $25 \%$ & $39 \%$ & $25 \%$ & $11 \%$ & $0 \%$ \\
\hline Professional integration & $20 \%$ & $36 \%$ & $39 \%$ & $5 \%$ & $0 \%$ \\
\hline $\begin{array}{l}\text { Ability to cooperate with } \\
\text { the environment }\end{array}$ & $18 \%$ & $48 \%$ & $29 \%$ & $4 \%$ & $0 \%$ \\
\hline $\begin{array}{l}\text { Able to adapt to changing } \\
\text { conditions }\end{array}$ & $22 \%$ & $46 \%$ & $24 \%$ & $9 \%$ & $0 \%$ \\
\hline Raising qualifications & $15 \%$ & $38 \%$ & $34 \%$ & $13 \%$ & $0 \%$ \\
\hline International experience & $13 \%$ & $39 \%$ & $26 \%$ & $17 \%$ & $4 \%$ \\
\hline Relations with superiors & $18 \%$ & $41 \%$ & $37 \%$ & $3 \%$ & $0 \%$ \\
\hline $\begin{array}{l}\text { Relationships with } \\
\text { colleagues }\end{array}$ & $24 \%$ & $46 \%$ & $27 \%$ & $3 \%$ & $0 \%$ \\
\hline Written communication & $16 \%$ & $39 \%$ & $32 \%$ & $13 \%$ & $0 \%$ \\
\hline Organization of own work & $17 \%$ & $52 \%$ & $25 \%$ & $5 \%$ & $0 \%$ \\
\hline Willingness to learn & $21 \%$ & $37 \%$ & $29 \%$ & $12 \%$ & $1 \%$ \\
\hline Work in information noise & $13 \%$ & $41 \%$ & $33 \%$ & $13 \%$ & $0 \%$ \\
\hline Cross-linking skills & $17 \%$ & $43 \%$ & $28 \%$ & $10 \%$ & $1 \%$ \\
\hline Building local partnerships & $15 \%$ & $45 \%$ & $29 \%$ & $10 \%$ & $1 \%$ \\
\hline $\begin{array}{l}\text { Concentration on event } \\
\text { participants }\end{array}$ & $30 \%$ & $42 \%$ & $22 \%$ & $5 \%$ & $0 \%$ \\
\hline
\end{tabular}

When assessing, following the assumed methodology, the aggregated components of employee competencies (Figure 2), the highest-rated were hard competencies, the ability to solve uncomplicated problems, and planning, interpersonal skills, and flexibility. Lower grades can be noted for technical skills.
Indications of the actual level of the personality traits of the team are visible in the ratings at the level of the highest values (4 and 5) for all traits except for "prioritizing". A very highly rated indicator of loyalty to the employer or kindness should be considered beneficial in managing companies (Figure 3 ).

Raising the competencies and qualifications of employees is perceived as one of the planned measures to overcome the pandemic crisis. Based on the interviews, the CEOs concluded the most pressing problems of the MICE sector require solutions in terms of competencies (Table 5).

The companies' CEOs were also asked to address the areas of human resources development in the sector in the near future, broken down into managers and operational employees (Figure 4). The third category concerned all employees, regardless of their position in the company ("does not matter"). In the opinion of $90 \%$ of respondents, the development of staff competencies should not depend on the position in the company. It is clear that managers are expected to be effective in obtaining external funding $(87 \%)$ and coordinating in conditions of imbalance (71\%), building relationships (65\%), and

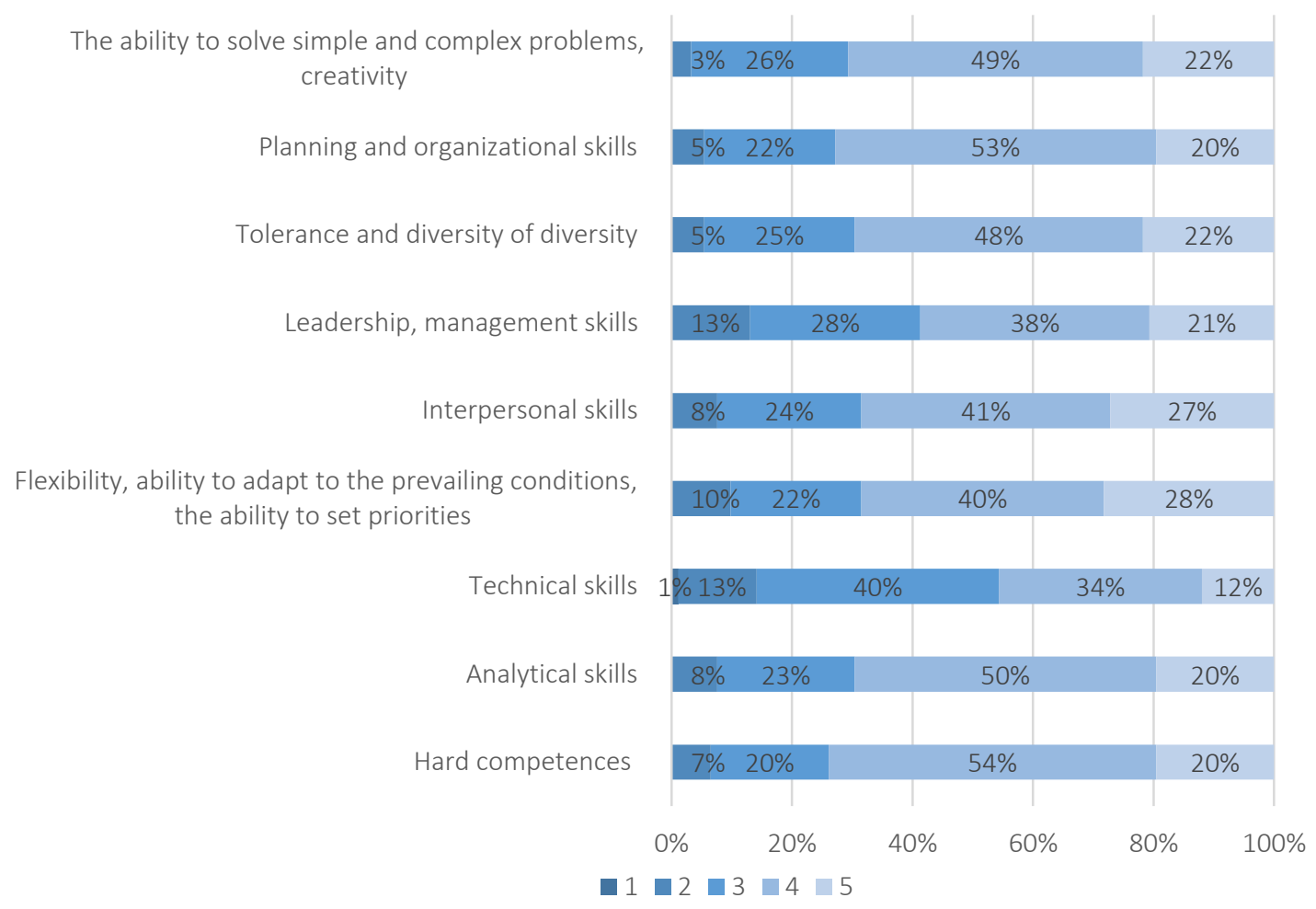

Figure 2. Aggregated components of employee competencies 
Setting priorities

Ability to conduct discussions

Control

Kindness

Scrupulousness

Duty

Creativity

Loyalty to the employer

Empathy

Assertiveness

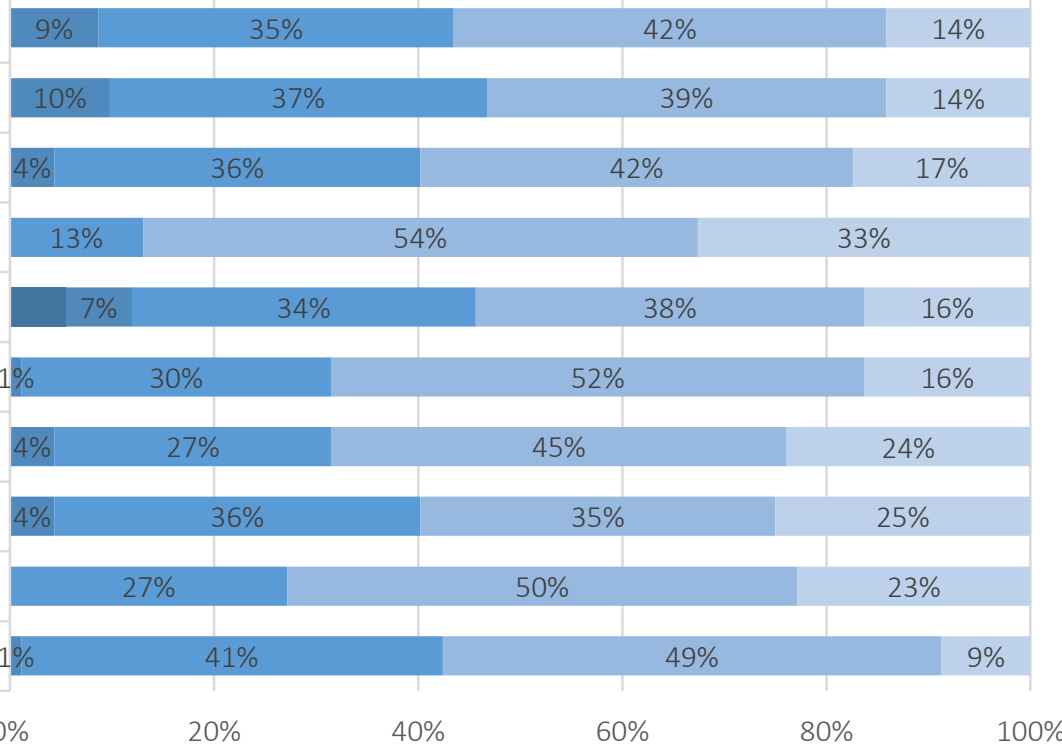

घ $12 \square 3 \square 4 \square 5$

Figure 3. The level of personality traits of the enterprise team

Table 5. The indication of the desired sector competencies to overcome the crisis

Source: Own study.

\section{Kind of competency}

Digital competencies

How to change the business profile and acquire knowledge that allows you to apply for EU grants

Crisis management

Adaptation to change, change management, resignation from old habits and solutions mix of competencies in one person and looking for new solutions, focusing on the quality of the service and individual requirements of the participant

Support in the field of soft skills as well as flexibility and openness to team changes

Continuous improvement of qualifications and a wide exchange of knowledge about the MICE sector on international markets and an attempt to make the best use of the experiences of these organizers

Implementation of events/conferences in the hybrid or online formula

Technical possibilities of hybrid events

Work ethic with clients, responsibility

Professional development is always important; the time we have been given should be used to expand our competencies

Skills in managing online events during a pandemic and internet marketing skills; stress management, compliance with new technologies Lack of hard skills in the IT area

Lack of competence and appropriate standards. Sometimes I feel that our company has stopped growing especially now during a pandemic

MICE survival strategies are insufficiently described. Due to severe travel restrictions and border closures, the mice industry has faced a demand reduction. The companies faced financial, economic, and mental problems

A completely new era has dawned. What worked in the last year before COVID-19 doesn't work anymore. The most pressing problem is the lack of general skills and adaptation methods to support the MICE sector

sustainable development along with CSR (58\%). Operational employees themselves are expected to be independent in the implementation of tasks (71\%), skilled in handling new technologies $(65 \%)$, or flexible (58\%). A significant percentage of CEOs indicated the need for new employee competencies (48\%).
However, in individual interviews with the managers of meeting industry companies, free statements were obtained regarding the assessment of the prospect of recovery after the pandemic, broken down by the segment of congresses and conferences, incentive trips, and events and fairs. Many of which indicate the need to improve competencies (Table 6). 
Staff improvement is not necessary

Sustainable development, corporate social responsibility

Expanding general knowledge

Building relationships, image and ethics "stay with us"

Effectiveness in conditions of imbalance (financial, ...

Independence in the implementation of tasks

New communication techniques

Flexibility of professional competencies

New competencies

Skills in handling new technologies

Efficiency in obtaining external sources of financing

Sanitary procedures
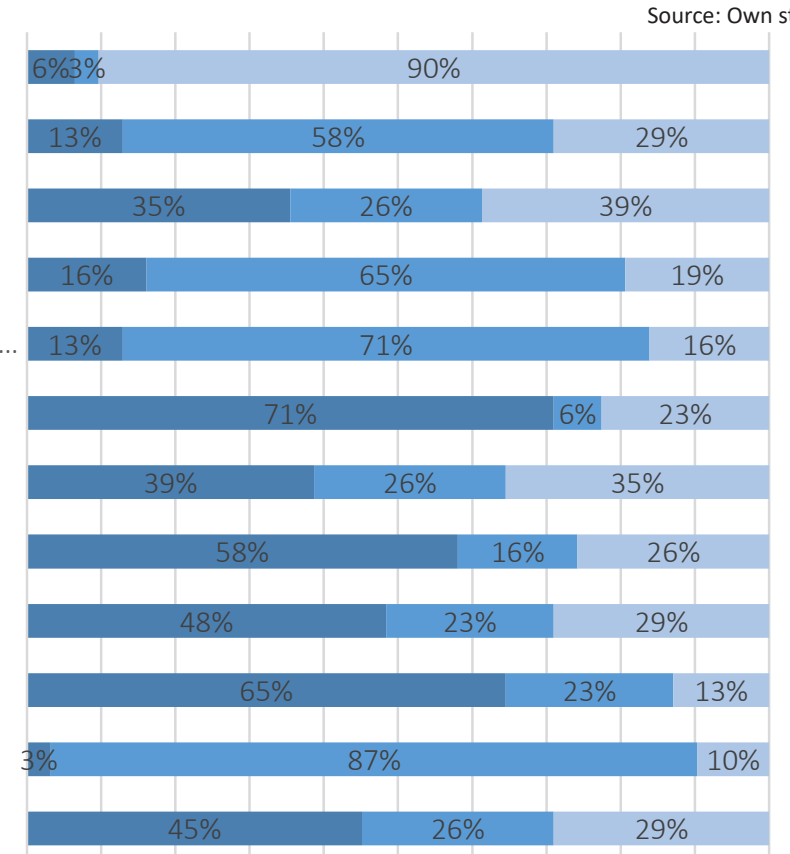

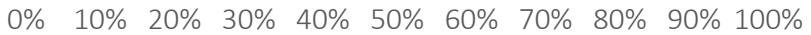

Operational staff $\square$ Managers $\square$ Does not matter

Figure 4. Areas of staff development in the MICE sector in the near future

Table 6. Opinions of CEOs on the assessment of the prospects for recovery by segment

Source: Own study.

\section{In the segment of congresses and conferences}

This will be the latest recovery segment, with a significant share of hybrid events.

Associations will permanently include hybrid and virtual formulas in the organization of events. The geographic rotation will change in favor of smaller regional events versus global major events. The return to the volume of projects from 2019 will be possible in 2024 at the earliest.

Rebuilding the segment in the pre-pandemic formula will be difficult, but possible. Many events will be organized in a hybrid way, in a large sanitary regime, but they need to organize traditional meetings involving direct interpersonal contact will return.

It will take at least a few years to recover to the pre-pandemic state. During this time, such events will take place in a hybrid or online formula. The speed of the worldwide immunization process will have a huge impact on the return to this type of face-to-face event. Depending on the pandemic situation in the coming years, however, smaller events of this type will prevail at the beginning. From the perspective of observing the situation, it seems that it will be different. Congresses and conferences will come back, but to what extent. I think that the number of participants will decrease, we will wait a long time for the return of big events, rather than expect smaller ones.

\section{In the incentive travel segment}

Due to the proximity of physical contact, the segment will recover as the pandemic subsides.

In 2021, only business trips will return, but to a significantly limited extent, incentives will return in 2022 and corporations will pay more attention to the sanitary safety of the destination country, and they will prioritize sustainable destinations and a high level of proecological behavior.

Full loosening of sanitary restrictions will allow us to return to the incentive market; the sector will return to "normal" at the latest of all. First, all travel restrictions, quarantine requirements, etc. must be removed. Corporations are still working online, so until they return to work in the "real world" it is difficult to talk about incentive travel.

Long-term, 3-4 years, more events in the country.

Many companies are already thinking about organizing typical incentive trips and returning to meetings in interesting places in a traditional form. Of course, the sanitary regime is a priority.

A faster recovery can be expected in this segment than in the congresses and conferences segment. I think incentive travel to Poland will start to recover very slowly in the second half of the year. However, the groups will be much smaller, they will come mostly from the EU and countries neighboring Poland, and the budgets allocated to this type of trip will be cut by clients.

Incentive travel will come back because motivation, especially nowadays, is important. However, the trips will focus on small groups with a very interesting, exclusive program. 
Table 6 (cont.). Opinions of CEOs on the assessment of the prospects for recovery by segment

\section{In the segment of events}

Corporations' attitudes towards the organization of events are also unknown as far as possible and hybrid concepts.

Events will recover in about 2 years, but this is the fastest anyway compared to other sectors when they can recover to pre-pandemic levels.

Probably large principals will limit the number of events.

The organizers are already planning new events, but to a much lesser extent in terms of the number of participants. The number of participants will gradually increase over time.

It will take at least 2-3 years for the state to recover from before the pandemic. During this time, such events will take place in a hybrid formula or online in specially prepared studios and locations.

People are fed up with sitting at remote events. The assumption of events is the fact that the participants experience some impressions, they meet, these are the factors that make the events happen. Events will come back, but they will also be limited.

We are not positive about these events, as we cannot rule out further epidemics such as the one for which we were not prepared.

\subsection{Competencies in the opinion of employees}

The competencies of the CEO were first assessed by the employees of the meetings industry sector (Table 7). They are divided into four categories, namely: always, often, occasionally, basically never. It can be concluded that the evaluation is relatively critical because only the category ("takes full responsibility for his decisions”) was indicated by the highest percentage of employees (35\%). It can be assumed that the distribution of the three categories is relatively uniform from "always" to "occasionally".

The self-assessment of own social competencies was measured on a scale of 1 (low) to 5 (high). Except for the "influencing" competency, the distribution of responses does not indicate that any of them can be distinguished in a special way (Table 8).

Table 7. Assessment of the competencies of the CEO

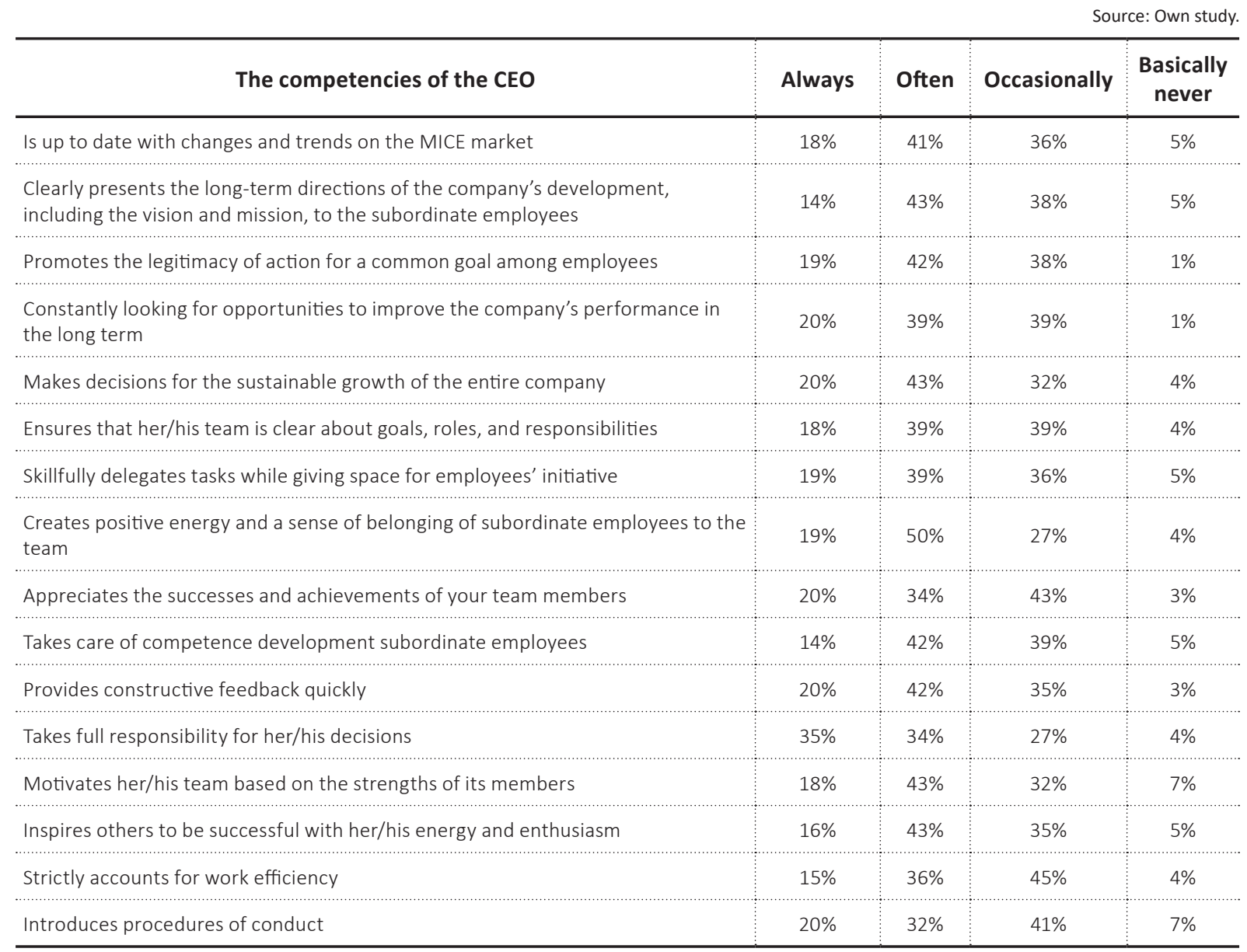


Table 8. Personal social competencies

Source: Own study.

\begin{tabular}{|c|c|c|c|c|c|}
\hline $\begin{array}{c}\text { Type of personal } \\
\text { competencies }\end{array}$ & 5 & 4 & 3 & 2 & 1 \\
\hline $\begin{array}{l}\text { Building relationships with } \\
\text { customers }\end{array}$ & $23 \%$ & $43 \%$ & $30 \%$ & $4 \%$ & $0 \%$ \\
\hline Ethics at work & $27 \%$ & $43 \%$ & $28 \%$ & $1 \%$ & $0 \%$ \\
\hline Ethics in dealing with clients & $28 \%$ & $46 \%$ & $22 \%$ & $4 \%$ & $0 \%$ \\
\hline Interpersonal communication & $26 \%$ & $43 \%$ & $20 \%$ & $11 \%$ & $0 \%$ \\
\hline Availability & $23 \%$ & $36 \%$ & $30 \%$ & $11 \%$ & $0 \%$ \\
\hline $\begin{array}{l}\text { Coping with conflict } \\
\text { situations }\end{array}$ & $19 \%$ & $35 \%$ & $34 \%$ & $11 \%$ & $1 \%$ \\
\hline Problem and conflict solving & $22 \%$ & $30 \%$ & $34 \%$ & $12 \%$ & $3 \%$ \\
\hline Proper self-presentation & $22 \%$ & $35 \%$ & $31 \%$ & $12 \%$ & $0 \%$ \\
\hline $\begin{array}{l}\text { Motivating yourself and } \\
\text { others }\end{array}$ & $22 \%$ & $27 \%$ & $32 \%$ & $18 \%$ & $1 \%$ \\
\hline $\begin{array}{l}\text { Emotional bond with the } \\
\text { company }\end{array}$ & $27 \%$ & $30 \%$ & $31 \%$ & $11 \%$ & $1 \%$ \\
\hline Professional integration & $23 \%$ & $30 \%$ & $38 \%$ & $9 \%$ & $0 \%$ \\
\hline $\begin{array}{l}\text { Ability to cooperate with the } \\
\text { environment }\end{array}$ & $26 \%$ & $34 \%$ & $32 \%$ & $8 \%$ & $0 \%$ \\
\hline $\begin{array}{l}\text { Ability to adapt to changing } \\
\text { conditions }\end{array}$ & $24 \%$ & $35 \%$ & $31 \%$ & $9 \%$ & $0 \%$ \\
\hline Raising qualifications & $23 \%$ & $31 \%$ & $28 \%$ & $16 \%$ & $1 \%$ \\
\hline International expertise & $15 \%$ & $35 \%$ & $22 \%$ & $23 \%$ & $5 \%$ \\
\hline Relationships with superiors & $24 \%$ & $34 \%$ & $26 \%$ & $16 \%$ & $0 \%$ \\
\hline Influencing & $9 \%$ & $38 \%$ & $28 \%$ & $22 \%$ & $3 \%$ \\
\hline Relationships with colleagues & $34 \%$ & $39 \%$ & $20 \%$ & $7 \%$ & $0 \%$ \\
\hline Written communication & $38 \%$ & $35 \%$ & $16 \%$ & $11 \%$ & $0 \%$ \\
\hline Organization of own work & $27 \%$ & $42 \%$ & $20 \%$ & $11 \%$ & $0 \%$ \\
\hline Willingness to learn & $34 \%$ & $27 \%$ & $30 \%$ & $9 \%$ & $0 \%$ \\
\hline $\begin{array}{l}\text { Working in information } \\
\text { overload }\end{array}$ & $24 \%$ & $30 \%$ & $30 \%$ & $15 \%$ & $1 \%$ \\
\hline Skills crossing & $24 \%$ & $36 \%$ & $26 \%$ & $14 \%$ & $0 \%$ \\
\hline Ability to work remotely & $28 \%$ & $28 \%$ & $24 \%$ & $11 \%$ & $8 \%$ \\
\hline Ability to adapt to changes & $31 \%$ & $34 \%$ & $23 \%$ & $11 \%$ & $1 \%$ \\
\hline Flexibility in operation & $28 \%$ & $36 \%$ & $19 \%$ & $15 \%$ & $1 \%$ \\
\hline $\begin{array}{l}\text { Ability to take on new } \\
\text { challenges }\end{array}$ & $28 \%$ & $36 \%$ & $22 \%$ & $14 \%$ & $0 \%$ \\
\hline
\end{tabular}

Aggregated competencies at the level of indicators 4 and 5 are assessed by no less than $47 \%$ of the respondents (Table 9). The lowest values, at levels 1 and 2 combined, were awarded to toleration and awareness of diversity (21\%).

Research results show that the CEOs in the MICE sector already have a high level of competencies, and at the same time articulate a desire to further improve them. Especially in areas that strengthen the ability to develop and maintain a business in a sector that is likely to recover slowly at the latest. In addition to the knowledge and skills related to the professionalization of operating activities, the need to acquire competencies allowing for overcoming the pandemic crisis, and exemplified by, for example, change and risk management or new technologies, was emphasized. Business psychology may play a significant role too in formal or non-formal education. The paper showed the existing competency gaps. The main accent of the competency gap is related to soft skills. The phenomenon of complementing competencies does not only apply to employees but also CEOs.

\section{DISCUSSION}

The subjective and objective scope adopted in these studies has no equivalents in the literature on the meetings industry. So far, the focus has been more on the diagnosis of the educational process itself, mainly of students (Sox, 2021; Marton et al., 2018). The obtained results diagnose the condition of entrepreneurs' competencies in the industry and indicate the desired direction of the evolution of competencies and the processes of their acquisition. Firstly, building relationships within the company, including between the $\mathrm{CEO}$ and employees (and the results of CEO management skills assessment articulated by employees indicate that

Table 9. Aggregated components of competencies of the employees

\begin{tabular}{|c|c|c|c|c|c|c|c|c|}
\hline Scale & $\begin{array}{l}\text { Analytical } \\
\text { skills }\end{array}$ & $\begin{array}{c}\text { Technical } \\
\text { skills }\end{array}$ & $\begin{array}{l}\text { Flexibility, ability } \\
\text { to adapt to } \\
\text { the prevailing } \\
\text { conditions, the } \\
\text { ability to set } \\
\text { priorities }\end{array}$ & $\begin{array}{l}\text { Interpersonal } \\
\text { skills }\end{array}$ & $\begin{array}{c}\text { Leadership, } \\
\text { management } \\
\text { skills }\end{array}$ & $\begin{array}{l}\text { Toleration } \\
\text { and } \\
\text { awareness } \\
\text { of diversity }\end{array}$ & $\begin{array}{c}\text { Planning and } \\
\text { organizational } \\
\text { skills }\end{array}$ & $\begin{array}{c}\text { Ability } \\
\text { to solve } \\
\text { simple and } \\
\text { complex } \\
\text { problems, } \\
\text { creativity }\end{array}$ \\
\hline 1 & $0 \%$ & $0 \%$ & $3 \%$ & $0 \%$ & $0 \%$ & $3 \%$ & $0 \%$ & $1 \%$ \\
\hline 2 & $4 \%$ & $7 \%$ & $12 \%$ & $14 \%$ & $9 \%$ & $18 \%$ & $11 \%$ & $9 \%$ \\
\hline 3 & $34 \%$ & $30 \%$ & $39 \%$ & $27 \%$ & $22 \%$ & $32 \%$ & $24 \%$ & $23 \%$ \\
\hline 4 & $45 \%$ & $42 \%$ & $36 \%$ & $41 \%$ & $49 \%$ & $23 \%$ & $45 \%$ & $46 \%$ \\
\hline 5 & $18 \%$ & $22 \%$ & $9 \%$ & $19 \%$ & $20 \%$ & $24 \%$ & $20 \%$ & $20 \%$ \\
\hline Total & $100 \%$ & $100 \%$ & $100 \%$ & $100 \%$ & $100 \%$ & $100 \%$ & $100 \%$ & $100 \%$ \\
\hline
\end{tabular}


there is a gap in this respect), Secondly, external relationships with all actors in the supply chain in the sector.

The exploitation and further development of the existing opportunities of meeting industry can only be realized in close cooperation of the actors of the profession (Celuch, 2018), as evidenced by the need for competence in building relations with the environment. The trends in the organization of meetings, the purchase of services, and the role of PCO intermediaries are likely to change as well. Already before the pandemic, such changes were observed: took over from PCO over more and more tasks by the secretariats of the organizations, congresses often tend were becoming "hamburger conferences" with very low participation fees to increase the number of participants, so all other services have to be ordered separately, optional programs are booked individually and frequently at the accommodation, the trends of the exhibition's segment is that they are less and less considered to be purely exhibitions, and other functions and contents, such as the nature of a show or the parallel organization of smaller meetings or finally the phenomenon of the growing importance of the so-called second choice cities in the decision on the location of the event (Załoga, 2013). These seemingly very technical and logistic trends will have to be reflected in the skills and competencies of the CEO and employees of the meetings industry sector.

The literature indicates that the acceptance of changes in enterprise management by managers depends on their personality factors and requires the attitude of a "change leader". To a large extent, the recipe for success is related to the activity of managers and their ability to motivate their employees to follow this process of change. Introducing a new way of thinking and convincing employees to it requires exceptional competencies from managers (Marez, 2020; Whiddett \& Hollyforde, 2003; Blackburn et al., 2013; Filipowicz, 2016; Hui-Wen, 2014; Okumus \& Wong, 2004).

All these circumstances should cause changes in the formal education process for the sector, recommended over the years (Mezirow, 2007; Walas, 2019). The survey revealed that both the employees and the management in the MICE sector are prepared for a changing world, although the recovery from the crisis caused by the pandemic is perceived as a difficult and in some cases slow process, depending on the MICE segment and the preparedness of the companies. Raising the qualifications of the staff of the meetings industry sector will be a challenge for formal and non-formal education (training, courses) shortly in several dimensions (CTHRC, 2011). Firstly, adapting education programs quickly or modifying them to the educational needs. Secondly, the treatment of the MICE sector in the European Qualifications Framework (EQF) and the national levels of qualifications in individual EU countries. For example, the Polish tourism qualifications framework does not cover this sector at all. And thirdly, there may be a need to supplement educational staff, in particular at the level of higher education. The biggest challenge for the education sector will be the ability to move away from the design of programs based on the transfer of knowledge towards the methodology of personality profiling and the development of soft skills.

\section{CONCLUSIONS}

The study aimed to diagnose the competencies of employees in the meetings industry sector. The focus was on the identification of the social competencies, the aggregate competencies of employees, the self-assessment by the CEO own managerial competencies, the employee assessment of the CEO's competencies, the personality traits of the team, as well as human resources as a tool for regaining competitiveness after the pandemic crisis. The research hypothesis assumed that the level of competencies is assessed as high and their improvement mainly concerns soft skills and is seen by the team as an opportunity for development and recovery from the pandemic crisis.

The obtained research results confirmed the hypothesis of high competencies in enterprises from the meetings industry. None of the compiled social competencies of the team obtained less than $52 \%$ of responses al- 
together at levels 4 and 5 on a five-point scale (Table 4). At the same time, they showed awareness of the need to further improve them, in particular in the area of soft skills (like relationships and ethics with customers, and at work interpersonal communication) and factors for faster reconstruction of the sector.

The development of staff competencies in the near future (Figure 4), in the opinion of $90 \%$ of respondents, should not depend on the position in the company. Managers are expected to be effective in obtaining external funding (87\%) and coordinating in conditions of imbalance (71\%), building relationships (65\%) and sustainable development along with CSR (58\%). Operational employees themselves are expected to be independent in the implementation of tasks (71\%), skilled in handling new technologies (65\%), or flexible (58\%). Interestingly, a significant percentage of CEOs (48\%) indicated the need for new competencies.

The CEOs must pay attention to the level of their own management competencies because, in the opinion of employees, these are not generally effective and team-building. A competencies gap of CEOs in company management was identified because each of the 16 management skills proposed for the assessment only obtained the status "occasionally" in the assessment of $27 \%$ to $45 \%$ of employees (Table 7 ).

They articulate a desire to further improve HR. Especially in areas that strengthen the ability to develop and maintain a business in a sector that is likely to recover slowly at the latest. In addition to the knowledge and skills related to the professionalization of operating activities, the need to acquire competencies allowing for overcoming the pandemic crisis, and exemplified by, for example, change and risk management or new technologies, was emphasized (Table 5). Business psychology may play a significant role too in formal or non-formal education. The paper showed the existing competency gaps. The main accent of the competency gap is related to soft skills. The phenomenon does not only apply to employees but also CEOs.

The research results also indicate the desired direction of possible modification of formal and informal education (from universities to training companies). In many ways the sector will be different from before, which will require new competencies and skills from management and workers, the more so as corporations signal changes in the business travel policy.

\section{AUTHOR CONTRIBUTIONS}

Conceptualization: Bartłomiej Walas.

Data curation: Anna Oleksa-Kaźmierczak.

Formal analysis: Marek Nocoń, Sandor Nemethy.

Funding acquisition: Bartłomiej Walas, Marek Nocoń.

Investigation: Sandor Nemethy, František Petrovič.

Methodology: Bartłomiej Walas.

Project administration: Marek Nocoń.

Software: Anna Oleksa-Kaźmierczak.

Supervision: Marek Nocoń.

Validation: Sandor Nemethy, František Petrovič.

Visualization: Anna Oleksa-Kaźmierczak.

Writing - original draft: Bartłomiej Walas, Marek Nocoń, Sandor Nemethy, Anna Oleksa-Kaźmierczak. Writing - review \& editing: Bartłomiej Walas, Sandor Nemethy, František Petrovič.

\section{ACKNOWLEDGMENT}

This study was done in frames of the project "Vocational competences in MICE sector" co-financed in frames of European Union program Erasmus + as part of the program The Dialog for Transformation, Erasmus+, 2020-2021. 


\section{REFERENCES}

1. Aburumman, A. A. (2020). COVID-19 impact and survival strategy in business tourism market: the example of the UAE MICE industry. Humanities and Social Sciences Communications, 7, 141. https://doi.org/10.1057/s41599020-00630-8

2. Allied Market Research. (2019). MICE industry by Event Type: Global opportunity analysis and industry forecast 2018-2025 (Report). Allied Market Research. Retrieved from https://www. researchandmarkets.com/reports/5457293/mice-industry-byevent-type-global-opportunity

3. Argyle, M (2002). Psychologia stosunków międzyludzkich. Wydawnictwo Naukowe PWN. (In Polish).

4. Bevins, F., Bryant, J., Krishnan, Ch., \& Law, J. (2020, April 3). Coronavirus: How should US higher education plan for an uncertain future? McKinsey \& Company. Retrieved August 11, 2021, from https://www.mckinsey.com/industries/public-and-social-sector/ our-insights/coronavirus-howshould-us-higher-education-planfor-an-uncertain-future

5. Blackburn, R. A., Hart, M., \& Wainwright, T. (2013). Small business performance: business, strategy and owner-manager characteristics. Journal of Small Business and Enterprise Development, 20(1), 8-27. https://doi. org/10.1108/14626001311298394

6. Błaszczyk, I., Fanderowska, P., Wirtel, W., Faracik-Leśniak, A., Hallier, J., Jędrocha, A., Młynarczyk, M., Paradowski, K., Wodziańska, A., Zalewski, M., Andrukowicz, M., Baran, P., Bączek, P., Berbeka, J., Borodako, K., Chmura, K., Chwastek-Pluta, J., Cieślikowski, M., Florek, J., ... Zając, B. (2021). Protokół Kraków Network. (In Polish). Retrieved August 11, 2021, from https:// krakownetwork.pl/wp-content/ uploads/2021/04/Protokol_Krakow_Network_PL.pdf

7. Borodako, K., Berbeka, J., \& Rudnicki, M. (2015). Zarządzanie innowacjami w przemyśle spotkań. Warszawa: CH Beck. (In Polish).

8. Burzyński, T. (2018). Badanie opinii pracodawców dotyczacej luki kompetencyjnej kadr w sektorze turystyki. Kraków: Instytutu Turystyki sp. z o.o. Retrieved August 11, 2021, from https:// ssl-kolegia.sgh.waw.pl/pl/KGS/ projekty/Documents/Raport\%20 PARP-ITK-stan\%2008-10-2019. pdf

9. Canadian Tourism Human Resource Council (CTHRC). (2011). Meeting and business events competency standards. Canadian Tourism Human Resource Council. Retrieved August 11, 2021 from https://www.mpi.org/docs/defaultsource/academy/mbecs-standards. pdf?sfvrsn=73a52050_2

10. Cedefop. (2020). National qualifications frameworks developments in Europe 2019. Qualifications frameworks: transparency and added value for end users. Luxembourg: Publications Office of the European Union. Retrieved from https://www.cedefop.europa.eu/ files/4190_en.pdf

11. Celuch, K. (2014). Meetings industry. Knowledge, product, motivation. Vistula Academy of Finance and Business.

12. Celuch, K. (2018). Impact of the events sector on the economy - case study of Poland. Ekonomiczne Problemy Turystyki, 4(44), 69-81. https://doi.org/10.18276/ ept.2018.4.44-07

13. Colardyn, D., \& Bjornavold, J. (2004). Validation of Formal, Non-Formal and Informal Learning: policy and practices in EU Member States. European Journal of Education, 39(1), 69-89. http://dx.doi.org/10.1111/j.01418211.2004.00167.x

14. European Commission (EC). (2008). Explaining the European Qualifications Framework for lifelong learning. Luxemburg: Office for Official Publications of the European Communities. Retrieved August 10, 2021 from https://europa.eu/europass/sys-
tem/files/2020-05/EQF-ArchivesEN.pdf

15. Filipowicz, G. (2016). Zarządzanie kompetencjami - perspektywa firmowa i osobista. Wolters Kluwer. (In Polish). Retrieved from https:// docplayer.pl/1970632-Zarzadzanie-kompetencjami-perspektywafirmowa-i-osobista.html

16. Górniak, J., Kocór, M., Czarnik, Sz., Magierowski, M., Kasparek, K., Jelonek, M., Turek, K., \& Worek, B. (2015). Polski rynek pracy - wyzwania i kierunki działań na podstawie badań Bilans Kapitału Ludzkiego 2010-2015. Polska Agencja Rozwoju Przedsiębiorczości. (In Polish). Retrieved from https://archiwum. ncbr.gov.pl/fileadmin/user_upload/import/tt_content/files/ POWR.03.01.00-IP.08-00-3MU18/ zalacznik_nr_12_polski_rynek_ pracy_wyzwania_i_kierunki_dzialan_na_podstawie_ badan_bilans_kapitalu_ludzkiego_20102015.pdf

17. Helgoy, I., \& Homme, A. (2015). Path-dependent Implementation of the European Qualifications Framework in Education. A Comparison of Norway, Germany and England. Journal of Comparative Policy Analysis: Research and Practice, 17(2), 124-139. http:// dx.doi.org/10.1080/13876988.201 3.849399

18. Hong, W. C. (2009). Global competitiveness measurement for the tourism sector. Current Issues in Tourism, 12(2), 105-132. https://doi. org/10.1080/13683500802596359

19. Hui-Wen, V. T. (2014). Constructing a competence model for international professionals in the MICE industry: An analytic hierarchy process approach. Journal of Hospitality, Leisure, Sport \& Tourism Education, 15, 34-49. https://doi.org/10.1016/j.jhlste.2014.04.001

20. International Congress and Convention Association (ICCA). (2020, May 12). ICCA announces record number of association meetings in 2019. Retrieved August 10, 
2021 from https://www.iccaworld. org/newsarchives/archivedetails. cfm?id=2894936

21. International Congress and Convention Association (ICCA). (2021, May 24). ICCA Skills - Leadership in Global Events Education. Retrieved August 13, 2021 from https://www.iccaworld.org/npps/ story.cfm? nppage $=5617513$

22. Kupczyk, T., \& Stor, M. (2018). Zarzadzanie kompetencjami - teoria, badania i praktyka biznesowa. Wyższa Szkoła Handlowa we Wrocławiu. (In Polish). Retrieved from https:// docplayer.pl/105993089-Zarzadzanie-kompetencjami.html

23. Marez, K. (2020). Professional recommendation for restarting exhibitions, conferences, business events for safe events after the COVID-19 epidemic. MaReSz handbook for safe restarting of events. Budapest: Magyarországi Rendezvényszervezök ésszolgáltatók Szovetsége. (In Hungarian). Retrieved August 10, 2021 from https://www.hah.hu/ files/2415/9255/6793/MaReSz COVID_19_kezikonyv.pdf

24. Marton, Zs., Birkner, Z., Keller, K., \& Berkesné Rodek, N. (2018). Marketing and management implications inherent in tourism safety. In Turizmus Bulletin, XVIII évfolyam 2 (pp. 12-20). Budapest: Heiling Média Kiadó Kft. (In Hungarian). Retrieved August 11, 2021 from https://mtu.gov.hu/documents/prod/TB-2018-2_1.pdf

25. Mezirow, J. (2007). An overview on transformative learning. In P. Sutherland \& J. Crowther (Eds.), Lifelong learning: Concepts and contexts (pp. 24-38). Routledge Taylor \& Francis Group.

26. Nagarjuna, L. (2016). Tourism Education Competencies and Tourism Industry Expectations. Lap Lambert Academic Publishing.

27. Next Tourism Generation Alliance (NTG). (2020, June 4). Skills sets in education and the tourism and hospitality industry in corona times. Retrieved August 12, 2021 from https://nexttourismgeneration.eu/ skills-sets-in-education-and-thetourism-and-hospitality-industryin-corona-times
28. Okumus, F. F., \& Wong, K. (2004). A critical review and evaluation of teaching methods of strategic management in tourism and hospitality schools. Journal of Hospitality \& Tourism Education, 16(2), 22-33. https://doi.org/10.108 0/10963758.2004.10696790

29. Phelan, K., Kavanough, R., Mills, J., \& Soocheong, J. (2009). Current Convention Course Offerings at the Top 25 Ranked Hospitality Management Undergraduate Programs: An Analysis of Objectives, Instructional Delivery, and Assessment Methods. Journal of Teaching in Travel \& Tourism, 9(1-2), 37-62. https://doi. org/10.1080/15313220903042038

30. Pilcher, N., Fernie, S., \& Smith, K. (2017). The impact of National Qualifications Frameworks: by which yardstick do we measure dreams? Journal of Education and Work, 30(1), 1-12. http://dx.doi.or g/10.1080/13639080.2015.1122178

31. Polish Tourism Organization (PTO). (2020). Study on impact of coronavirus on European convention sector. Retrieved August 11, 2021 from https://www.pot.gov. $\mathrm{pl} /$ en/poland-convention/news/ study-on-impact-of-coronaviruson-european-convention-sector

32. Shum, C., Gatling, A., \& Shoemaker, S. (2018). A model of hospitality leadership competency for frontline and director-level managers: Which competencies matter more? International Journal of Hospitality Management, 74, 57-66. https://doi.org/10.1016/j. ijhm.2018.03.002

33. Smółka, P. (2008). Kompetencje społeczne - uwarunkowania i metody pomiaru. In W. Ciarkowska \& W. Oniszczenko (Eds.), Szkice z psychologii różnic indywidualnych (pp. 258-268). Scholar. (In Polish).

34. Sox, C. B. (2021). A case study on revisiting meeting and event competency standards and student perspective. Journal of Convention \& Event Tourism, 22(4), 296-323. https://doi.org/10.1080/15470148. 2021.1879701

35. Statista Research Department. (2021, September 3). Statistics and facts on the meetings industry in Europe. Retrieved August 10, 2021 from https://www.statista.com/ topics/5118/meetings-industryin-europe/

36. Swarbrooke, J., \& Horne, S. (2001). Business Travel and Tourism. Butterworth-Heinemann.

37. Trinder, J. C. (2008). Competency standards - a measure of the quality of a workforce. The International Archives of the Photogrammetry, Remote Sensing and Spatial Information Sciences, XXXVII (B6a), 165-167. Retrieved August 12, 2021 from https://www. isprs.org/proceedings/XXXVII/ congress/6a_pdf/5_WG-VI-5/01. pdf

38. Walas, B. (2019). Trendy rozwojowe $w$ krajowej $i$ międzynarodowej edukacji turystycznej i jego zalecenia dla potrzeby projektu - ekspertyza dla projektu Sektorowa Rada ds. kompetencji turystyki. Rada ds. Kompetencji Sektora Turystyka Instytut Turystyki w Krakowie Sp. z o.o. (In Polish). Retrieved August 13, 2021 from https:// www.academia.edu/41522076/ Trendy_rozwojowe_w_krajowej_i_ międzynarodowej_edukacji_ turystycznej_i_jego_zalecenia

39. Walas, B. (2021). A Sustainable Tourism Policy for Kraków in the Years 2021-2028 Diagnosis and recommendations. City Hall of Krakow. http://dx.doi. org/10.13140/RG.2.2.11765.70883

40. Wang, J., Ayres, H., \& Huyton, J. (2010). Is Tourism Education Meeting the Needs of the Tourism Industry? An Australian case study. Journal of Hospitality \& Tourism Education, 22(1), 8-14. https://doi.org/10.1080/10963758. 2010.10696964

41. Whiddett, S., \& Hollyforde, S. (2003). Modele kompetencyjne w zarzadzaniu zasobami ludzkimi. Oficyna Ekonomiczna Grupa Wolters Kluwer. (In Polish).

42. Winterton, J., Le Deist, F. D., \& Stringfellow, E. (2006). Typology of knowledge, skills and competences: clarification of the concept and prototype. Luxemburg: Office for 
Official Publications of the European Communities. Retrieved from https://www.cedefop.europa. eu/files/3048_en.pdf

43. Wybrańczyk, K. (2021). Kompetencje menedżerów $w$ procesie restrukturyzacji naprawczej przedsiębiorstwa. Proksenia. (In Polish).

44. Załoga, W. (2013). Model kompetencji menedżera $\mathrm{w}$ nowoczesnej organizacji. Zeszyty Naukowe Uniwersytetu Przyrodniczo-Humanistycznego $w$ Siedlcach. Administracja i Zarzadzanie, 24(97), 449-468. (In Polish). Retrieved from https:// docplayer.pl/42054064-Modelkompetencji-menedzera-w-nowoczesnej-organizacji-model-ofcompetence-of-the-manager-inthe-modern-organization.html
45. Zmyślony, P., \& Piechota, N. (2014). Znaczenie przemysłu spotkań w kształtowaniu potencjału turystycznego miast. In K. Celuch (Ed.), Zarzadzanie i organizacja przemystu spotkań $w$ Polsce. Teoria i praktyka (pp. 103117). Szkoła Główna Turystyki i Rekreacji w Warszawie. (In Polish). Retrieved from http://media. wix.com/ugd/92f1c9_a0f9acd7f2954e5e9b4dd11acec50b48.pdf 